\title{
Inventory and Mapping of Land Resources for Land Use Planning Through Detail Soil Survey Coupled With Remote Sensing and GIS Techniques: A Case Study in Nagenahalli Watershed, Doddaballapur Taluk, Bangalore Rural District, India
}

\author{
C.N. Nalina*, K.S. Anil Kumar, K.G. Shilpa Shree, B. Narendra Babu, \\ K. Sudhir and A. Natarajan \\ Department of Soil Science and Agricultural Chemistry, UAS, GKVK, \\ Bangalore-560065, Karnataka, India \\ *Corresponding author
}

\section{A B S T R A C T}

\section{Keywords}

Detail soil survey, Land use planning,

Land resources,

Natural resource management,

Sustainable land use, Alternative land use, Remote sensing and GIS techniques.

Article Info

Accepted:

04 June 2017

Available Online:

10 August 2017
Planning for development of natural resources without endangering the environment is a crucial issue, which the world is facing today. Growing population pressure and human activities increases the demand on the limited land resources, both for agricultural and other land uses. To meet this unprecedented demand of land for various pursuits, it is imperative to develop land use plans which can counteract the detrimental effects on environment and at the same time improve productivity of land. The present study deals with the application of remote sensing and GIS for mapping of land resources of Nagenahalli watershed in Bangalore rural district of Karnataka. Base maps, google earth images, toposheets and satellite imagery $(1: 12,500$ scale) collected from Karnataka State Remote Sensing Application Centre, Bangalore have been used in the study. Maps on various themes, viz., land use, drainage, soil, slope, depth etc. have been generated using aforementioned satellite data coupled with ground truth. The analysis in a GIS system helped in bringing out maps and statistics with constructive options for alternate land use plans which are expected to be both productive and sustainable.

\section{Introduction}

The land resources are under severe strain due to the pressure of the growing population and competing demands of the various land uses. The key to meet the present day challenges lies in the integrated management of the natural resources. Therefore the knowledge of soil and land resources with respect to their spatial distribution, characteristics, potentials, limitations and their suitability for alternate land uses helps in formulating strategies to obtain higher productivity on sustained basis. The data required for farm planning can be obtained by carrying out detailed characterization and mapping of all the existing land resources like soils, climate, minerals and rocks, ground water, vegetation, crops, land use pattern etc. From the data collected, the problems and potentials of the area for agriculture development, suitable land use options and soils management 
aspects for each and every parcel of land holding can be identified easily. One of the basic requirements for land use planning is the availability of timely, accurate and up to date information on land use at the shortest possible time. This calls for systematic and reliable inventory of natural resources at a quicker phase through scientific and modern tools like remote sensing and geographic information system (GIS). These remote sensing techniques have proved to be rapid, reliable cost effective and provide quick information. Satellite remote sensing provides data for identification of watershed characteristics such as drainage, stream network, landforms etc., which could be used for proper management of watershed (Gawande, 1990). Generation of information on land qualities, through survey of land resources and mapping of spatial patterns of these natural landforms and features based on fine resolution satellite data besides providing relevant, reliable and timely information facilitates the creation of a comprehensive geo-database. Spatial analysis in GIS has enabled the generation of an environmentally and economically sound land use plan for implementation in the study area. Also use of this data in agricultural development planning could augment judicious application of inputs such as chemical fertilizers and better land use options will lead to optimal utilization of land resources and maintenance of soil health.

\section{Study area}

The area of study which is a part of Doddaballapur taluk, Bangalore rural district in Karnataka, located besides the GhatiSubhramanya high way which runs from Doddaballapur town, at the elevation range of 911 to $930 \mathrm{~m}$ above MSL. The village lies between $13^{\circ} 22^{\prime} 20.66^{\prime \prime} \mathrm{N}$ to $13^{\circ} 22^{\prime} 20.2^{\prime \prime} \mathrm{N}$ latitude and $77^{\circ} 32^{\prime} 55.30^{\prime \prime} \mathrm{E}$ to $77^{\circ} 33^{\prime} 27.7^{\prime \prime} \mathrm{E}$ longitude covering an area of 225.2 ha. Majority of population in the study area depend on agriculture for their livelihood and, the entire land use of the area is dependent on the onset of monsoon showers. Apart from this, wrong choice of crops, faulty agricultural practices, decrease in the soil fertility and imbalance in use of fertilizers, lack of appropriate cropping pattern and wrong choice of land use to exploit the full potentials of the resources by the farmers have greatly affected the productivity of the land resources. Since the function of land use planning is to guide decisions on land use in such a way that the resources of the environment are put to sustainable use, the present study has been undertaken with an aim not only to evaluate the potential of land resources of the region but to suggest alternative use for sustainability in the present environmental set up.

\section{Materials and Methods}

\section{Data used}

The micro-watershed was delineated using 1:12,500 (Scale) cadastral map as a base map and SOI toposheet $(57 \mathrm{G} / \mathrm{ll})$ to cover the whole village. Google earth image and satellite imagery of the watershed were used in conjunction with SOI toposheet to prepare thematic maps and to obtain physiographic information. Climatic data of the study area is obtained from Indian meteorological department (IMD). Water balance diagram was prepared using climatic and soil data of the study area by following the method suggested by Thornthwaite and Mather (1955).

Using base maps, Google earth images, satellite imagery and toposheets traversing was done for physiographic delineations in the study area. The site characteristics includes latitude, physiographic-unit, geology, parent material, rainfall, temperature, topography, elevation, erosion 
characteristics, runoff, drainage, stoniness, rock outcrops, natural vegetation and present land use and crop productivity of the study area were recorded in detail in the prescribed pro forma.

A tracing film was overlaid on the toposheet covering the study area to prepare the base maps. Boundary of the watershed and important land features like rivers, tanks, roads etc. were extracted. Thus a map having the above common land features was used as a base, it was overlaid with cadastral map, interpreted image and Google earth image to form the base for mapping.

GIS processing involved geo referencing of various thematic maps and vectorisation of the features using Arc GIS software. Simultaneously the attribute coding and the description for all feature classes were organized in master database tables. The topography was created and the master database was linked to respective themes. All the features were referenced with the standard codes. The soil, land use and watershed themes were built as polygon features, whereas streams and roads were built as line features and all these were included as shape files. Five transects were drawn along the direction of slope at different locations in the watershed by observing external land features like break in slope, erosion, gravel, stoniness etc. Site and soil characteristics were recorded on standard pro forma as per guidelines given in USDA Soil Survey Manual (1996).

The soil maps finalized in the field were traced, scanned and digitized using geographical information system (GIS) to get the soil map. It shows individual field boundaries, the survey numbers, soil series and its phases and other miscellaneous areas. Figure 1 shows methodology for preparation of soil map. From the soil map, thematic maps on soil depth, drainage, slope, soil erosion, surface texture, surface gravelliness, and rackiness in the study area were mapped. Land use/land cover mapping was carried out by visual interpretation techniques as per the land use land cover classification system developed by department of space (Anonymous, 1994).

Satellite imagery, google earth image and ancillary data like toposheet and other thematic maps were also referred. The interpreted details were then ground checked to validate and verify the present land use. The corrected details were then transferred on to a base map prepared from the toposheets, to get a final land use map. Figure 2 shows methodology followed in the preparation of land use/land cover map of the area.

\section{Results and Discussion}

The dominant geology of the area is Archaean granites and gneisses on upland and colluvium on convex lower sectors. Small patches are there with basic rocks in granitic landscape itself. Parthenium, Mimosa pudica, Pongamia, Lantana camera, Eupatorium odaratum and grasses are the major natural vegetation apart from forest species.

Rainfall is about $826.2 \mathrm{~mm}$ (IMD 2001). Rain fall received mainly from South West Monsoon and North- East also contributes to some extent. The rainy days extends from July to mid-October and maximum rainfall received in the month of mid-September followed by October.

The five driest months are November to middle of April. Mean annual temperature of area is $23.8{ }^{\circ} \mathrm{C}$. Mean annual soil temperature is $24.8^{\circ} \mathrm{C}$, mean annual summer soil temperature is $\quad 26.1^{\circ} \mathrm{C}$. Potential evapotranspiration ranged from 98.4 to 164.7 $\mathrm{mm}$, area qualifies for isohyperthermic soil temperature regime and Udic soil moisture regime. 


\section{Land use and cropping pattern}

Entire land use of the area is dependent on the onset of monsoon showers. Ragi and maize are the major crops in rainy season and vegetables like tomato, carrot, radish, kholkhol, cucumber chilly were also cultivated in irrigated areas.

The gently sloping uplands and some lands which are not having irrigation facilities were under eucalyptus plantation which is the prevailing practice in the study area. The land use map of Nagenahalli is shown in map 1.

The cropped land occupies 47.9 per cent of the total geographical, followed by cultivable waste which accounts for 19.5 per cent, lands with gentle slops and erosion problems are under eucalyptus plantation accounts for 16.2 of the total geographical area.

Ragi and red gram based cropping system is the major practice in the study area accounts for 41.5 per cent of the total cropped area followed by ragi based cropping system (30.2 $\%)$, maize based cropping system $(6.8 \%)$ and vegetable based cropping system $(5.2 \%)$.

The details on land use and cropping pattern for Nagenahalli are presented in figures 3 and 4.

The soils of Nagenahalli village occur on granite and granite gneiss land form and were characterized by the upland physiographic units such as level to nearly level linear uplands, level to nearly level uplands on convex upper sector, very gently sloping uplands on convex middle sector, on convex or concave lower sector and on concave lower sector.

In Nagenahalli village 5 soil series were identified and classified upto the family level. Soils were classified under Alfisols as per soil taxonomy. The 5 soil series were mapped into
15 mapping units (Table 1). A map showing soil phases and series association was prepared and shown in map 2. The optimal land use planning calls for identifying the activities or action plan for natural resources development based on potential and limitations of available resources.

The details of thematic maps which can be used as input for generating action plan are as under:

\section{Soil depth}

It determines the effective rooting depth of plants and the capacity of the soil to hold water and nutrients.

The limits used to group the soils into various depth classes in the survey are very deep (> $150 \mathrm{~cm})$ and moderately shallow $(50-75 \mathrm{~cm})$.

Very deep soils (50.3\%) occurred extensively in convex lower sector and convex middle sector of the uplands and about 40.60 per cent of the soils in the study area are moderately shallow in nature.

\section{Soil Drainage}

The soil drainage classes given by the soil survey (AISLUS, 1970) were applied to the soil-site data to arrive at the drainage class for the mapping units.

In Nagenahalli, very gently sloping upland soils occurred in the eastern region. Nearly level uplands occurred in the south eastern parts were well drained.

The soils belonging to very gently sloping and gently sloping uplands of northwest and south western parts were moderately well drained. Well drained soils occurred in large extent $(50.5 \%)$ than moderately well drained (40.4 $\%)$. 
Fig.1 Methodology for soil map preparation: Modified from Sathish (2002)

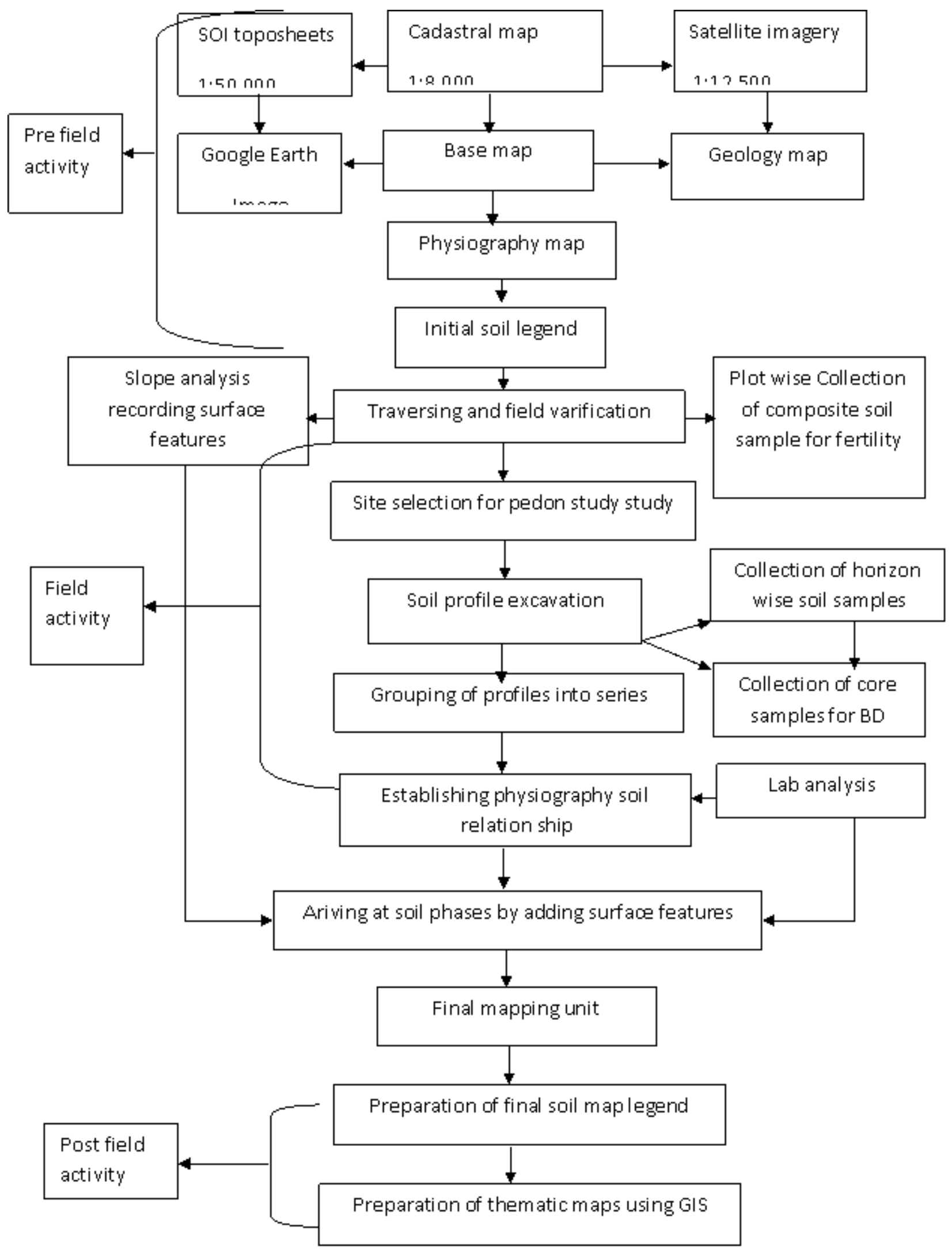


Fig.2 Methodology for preparation of land use/land cover map Modified from Sathish (2002)

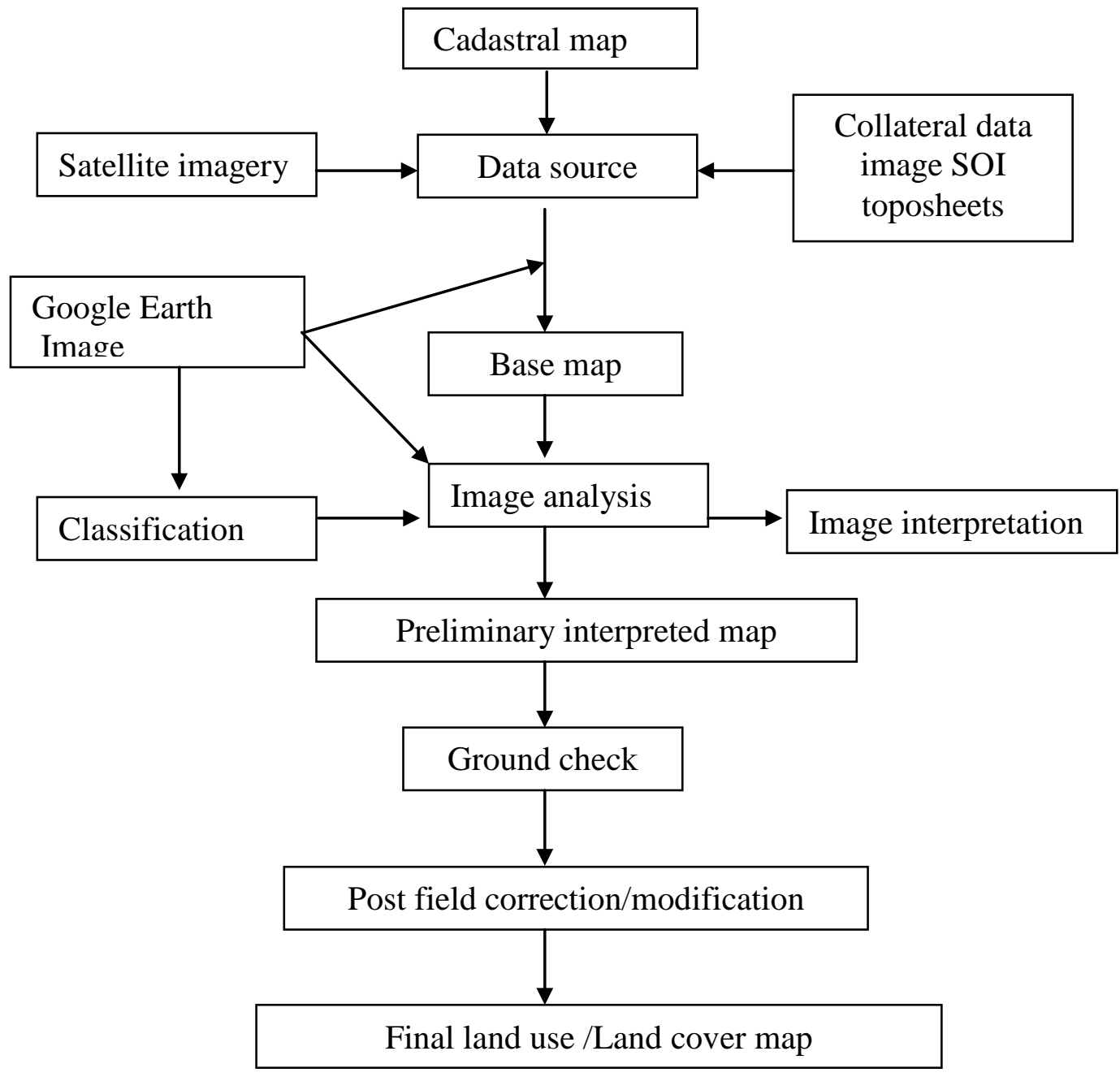

Fig.3 Land use pattern in Nagenahalli watershed, Doddaballapur taluk, Bangalore Rural District

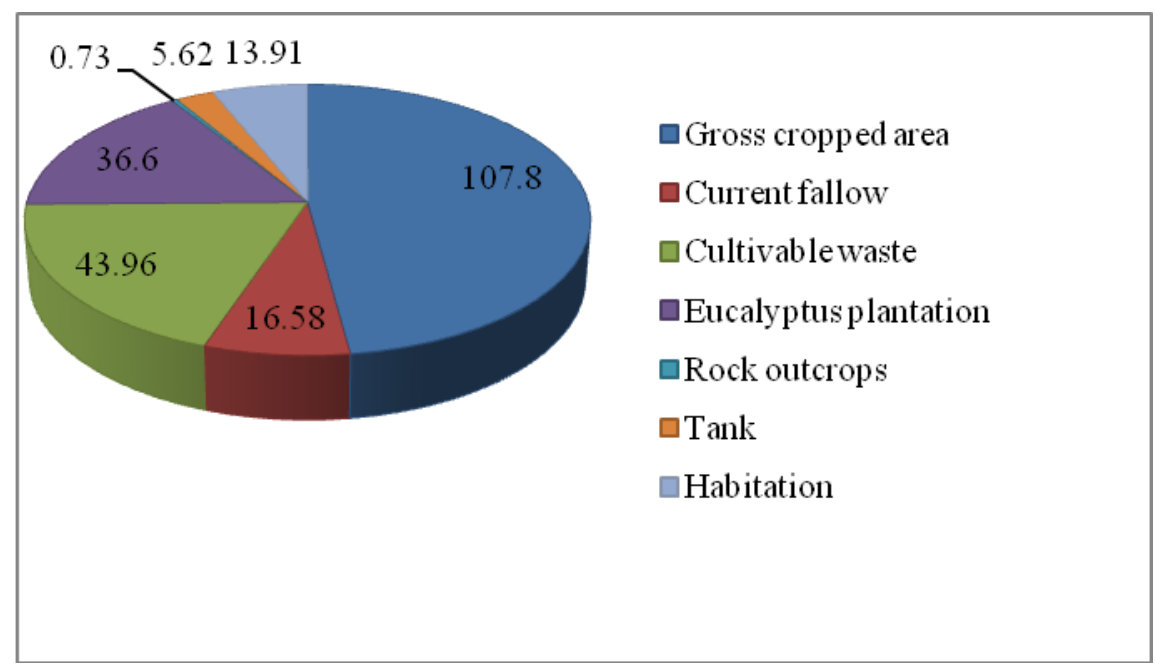


Fig.4 Cropping pattern in Nagenahalli watershed, Doddaballapur taluk, Bangalore Rural District

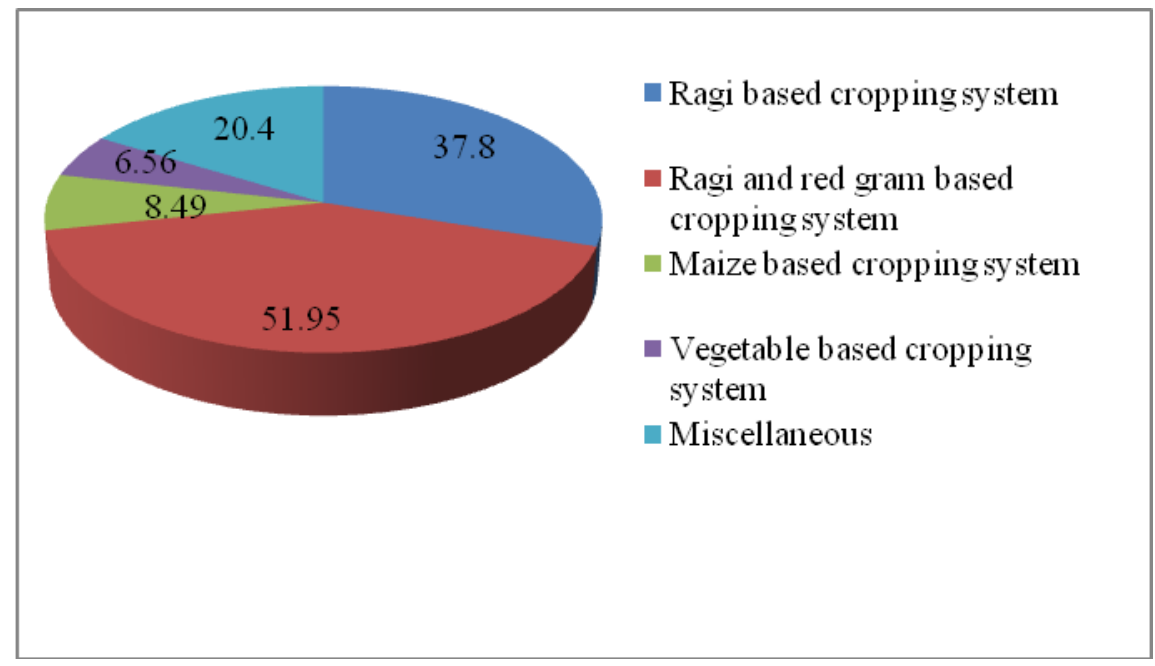

Table.1 Legend of soil map of Nagenahalli watershed Doddaballapur taluk, Bangalore rural District

\begin{tabular}{|c|c|c|}
\hline $\begin{array}{l}\text { Map } \\
\text { unit }\end{array}$ & $\begin{array}{l}\text { Mapping } \\
\text { legend }\end{array}$ & Description \\
\hline 1 & $\mathrm{NabB}$ & Nagenahalli a series, 1-3 per cent slope loamy sand surface texture. \\
\hline 2 & NahB & Nahenahalli a series, 1-3 per cent slope sandy clay loam surface texture. \\
\hline 3 & $\mathrm{NahC} 2$ & $\begin{array}{l}\text { Nagenahalli a series, } 3-5 \text { per cent slope sandy clay loam surface texture and } \\
\text { moderately eroded. }\end{array}$ \\
\hline 4 & $\mathrm{NbbC1}$ & $\begin{array}{l}\text { Nagenahalli b series, loamy sand surface texture, } 3-5 \text { per cent slope and } \\
\text { slightly eroded. }\end{array}$ \\
\hline 5 & NbcB2 & $\begin{array}{l}\text { Nagenhalli b series, sandy loam surface texture, } 1-3 \text { per cent slope and } \\
\text { moderately eroded. }\end{array}$ \\
\hline 6 & NcbB1 & $\begin{array}{l}\text { Nagenahalli c series, loamy sand surface texture, } 1-3 \text { per cent slope and } \\
\text { slightly eroded. }\end{array}$ \\
\hline 7 & NciA & Nagenahalli c series, sandy clay surface texture, $0-1$ per cent slope. \\
\hline 8 & NchB & $\begin{array}{l}\text { Nagenahalli c series, sandy clay loam surface texture with 1-3 per cent } \\
\text { slope. }\end{array}$ \\
\hline 9 & NchB2 & $\begin{array}{l}\text { Nagenahalli c series, sandy clay loam surface texture, } 1-3 \text { per cent slope and } \\
\text { moderately eroded. }\end{array}$ \\
\hline 10 & $\mathrm{NcmB}$ & Nagenahalli c series, clayey surface texture with 1-3 per cent slope. \\
\hline 11 & $\mathrm{NdcA}$ & Nagenahalli d series, sandy loam surface texture with $0-1$ per cent slope. \\
\hline 12 & $\mathrm{NdbBr}$ & $\begin{array}{l}\text { Nagenahalli d series, loamy sand surface texture with } 1-3 \text { percent slope and } \\
1-2 \text { per cent surface rock cover. }\end{array}$ \\
\hline 13 & $\mathrm{NdhC} 2$ & $\begin{array}{l}\text { Nagenahalli d series, sandy clay loam surface texture, } 3-5 \text { per cent slope } \\
\text { and moderately eroded. }\end{array}$ \\
\hline 14 & NecA1 & $\begin{array}{l}\text { Nagenahalli e series, sandy loam surface texture, } 0-1 \text { percent slope and } \\
\text { slightly eroded. }\end{array}$ \\
\hline 15 & NecB1 & $\begin{array}{l}\text { Nagenahalli e series, sandy loam surface texture, 1-3 percent slope and } \\
\text { slightly eroded. }\end{array}$ \\
\hline
\end{tabular}


Table. 2 Classes under different particulars and their extent of distribution in the Nagenahalli watershed

\begin{tabular}{|c|c|c|}
\hline \multirow{2}{*}{ Particulars } & \multicolumn{2}{|c|}{ Area covered } \\
\hline & Area (ha) & Per cent \\
\hline \multicolumn{3}{|c|}{ Soil Depth } \\
\hline Very deep & 113.30 & 50.30 \\
\hline Moderately shallow & 91.50 & 40.60 \\
\hline Miscellaneous & 20.40 & 9.00 \\
\hline \multicolumn{3}{|c|}{ Soil Drainage } \\
\hline Well drained & 113.80 & 50.50 \\
\hline Moderately well drained & 90.90 & 40.40 \\
\hline Miscellaneous & 20.40 & 9.00 \\
\hline \multicolumn{3}{|c|}{ Soil slope } \\
\hline Level to Nearly level (0-1\%) & 1.78 & 0.79 \\
\hline Very gently sloping (1-3\%) & 195.00 & 86.60 \\
\hline Gently sloping (3-5\%) & 7.90 & 3.50 \\
\hline Miscellaneous & 20.40 & 9.00 \\
\hline \multicolumn{3}{|c|}{ Soil Erosion } \\
\hline None & 110.50 & 49.00 \\
\hline Slight erosion & 31.50 & 14.00 \\
\hline Moderate erosion & 62.80 & 27.90 \\
\hline Miscellaneous & 20.40 & 9.00 \\
\hline \multicolumn{3}{|c|}{ Soil Texture } \\
\hline Loamy sand & 47.10 & 20.90 \\
\hline Sandy loam & 54.10 & 24.00 \\
\hline Sandy clay loam & 99.00 & 44.00 \\
\hline Sandy clay & 2.70 & 1.20 \\
\hline Clay & 1.80 & 0.80 \\
\hline Miscellaneous & 20.40 & 9.00 \\
\hline \multicolumn{3}{|c|}{ Surface rockiness } \\
\hline Non-rocky $(<0.1 \%$ cover $)$ & 202.20 & 89.80 \\
\hline Slightly rocky ( $1-5 \%$ cover $)$ & 2.60 & 1.10 \\
\hline Miscellaneous & 20.40 & 9.00 \\
\hline
\end{tabular}


Map.1 Land use map of Nagenahalli village

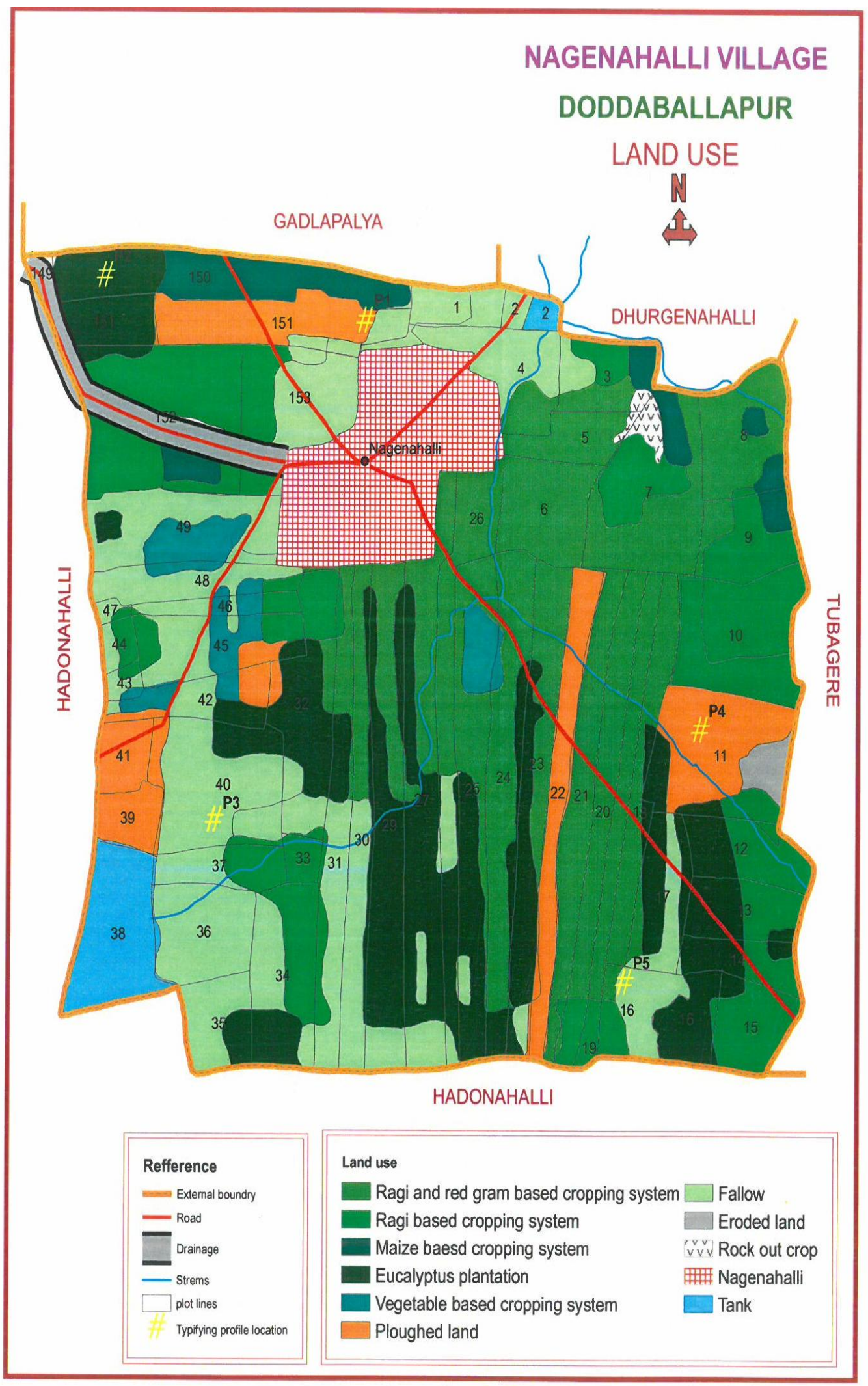


Map.2 Soil map of Nagenahalli village

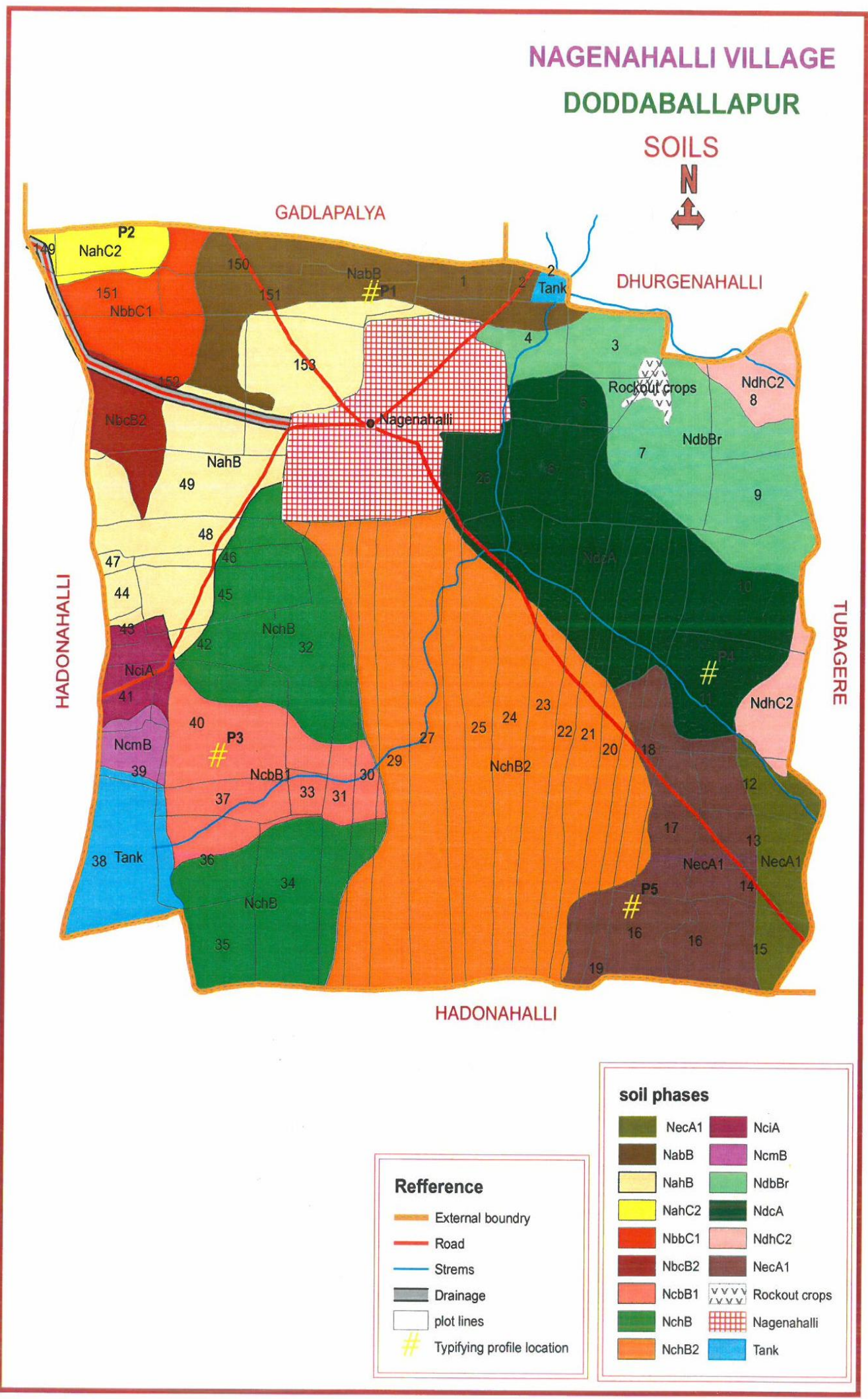


Map.3 Soil depth map of Nagenahalli village

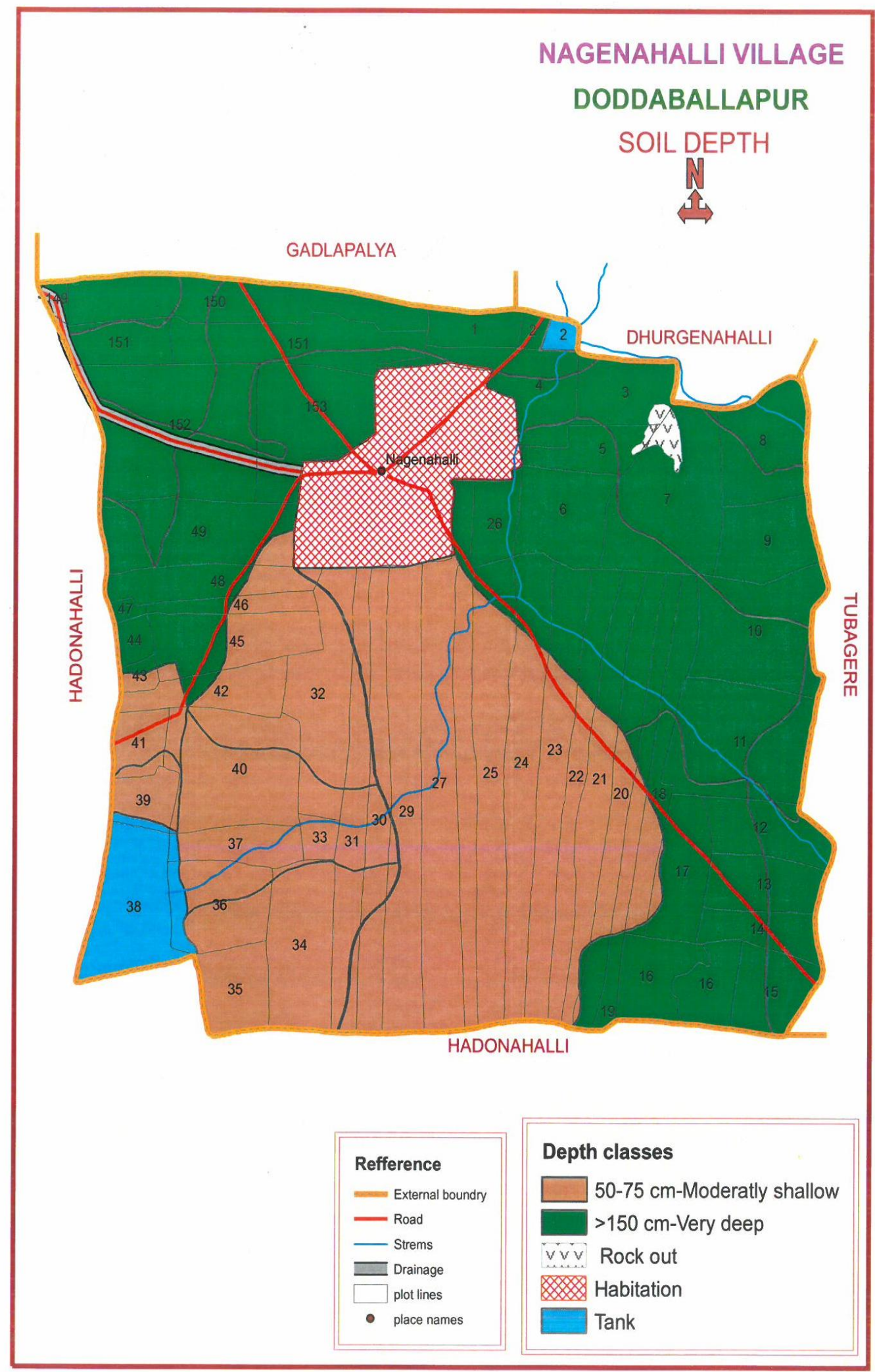


Map.4 Soil drainage map of Nagenahalli village

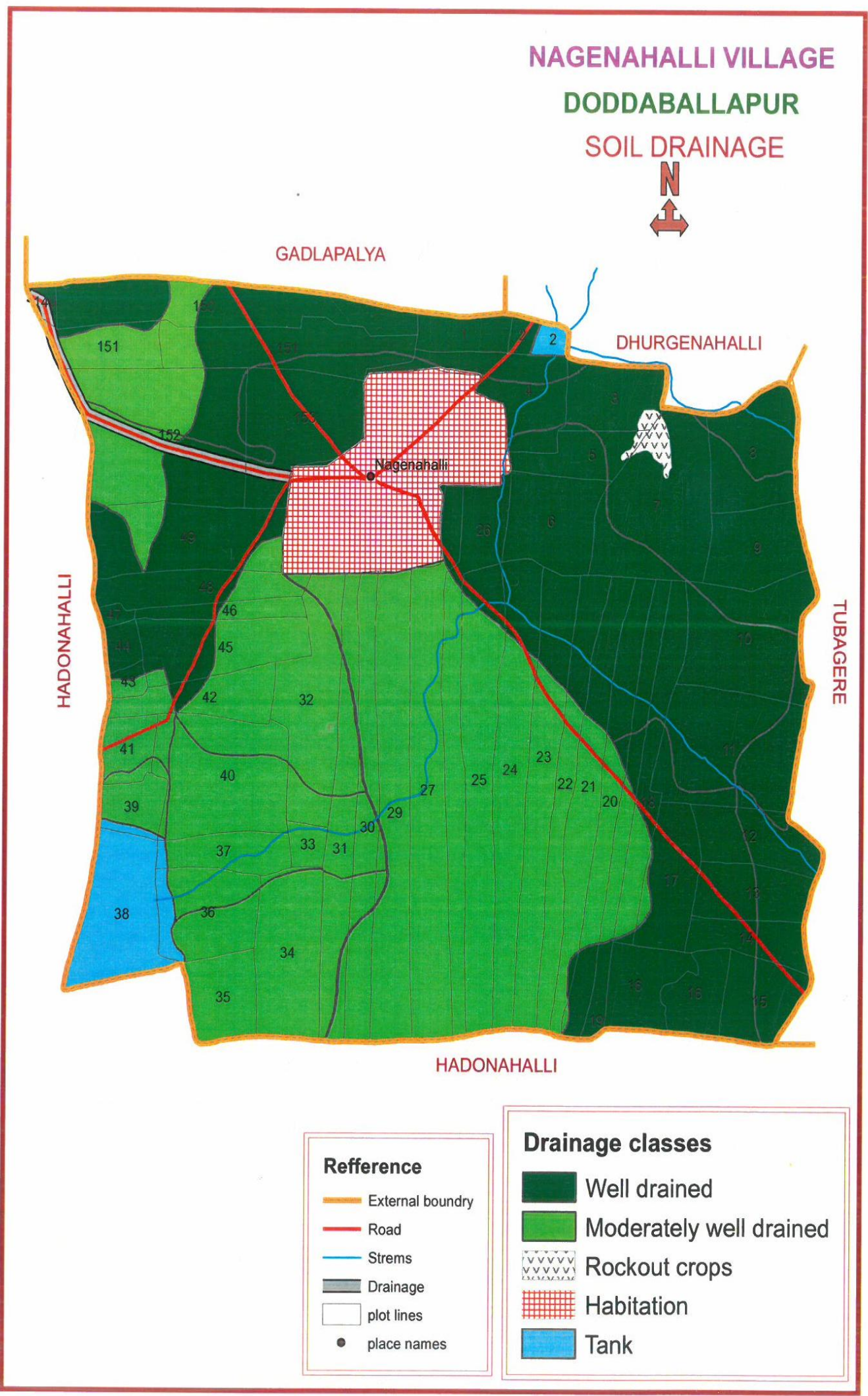


Map.5 Soil slope map of Nagenahalli village

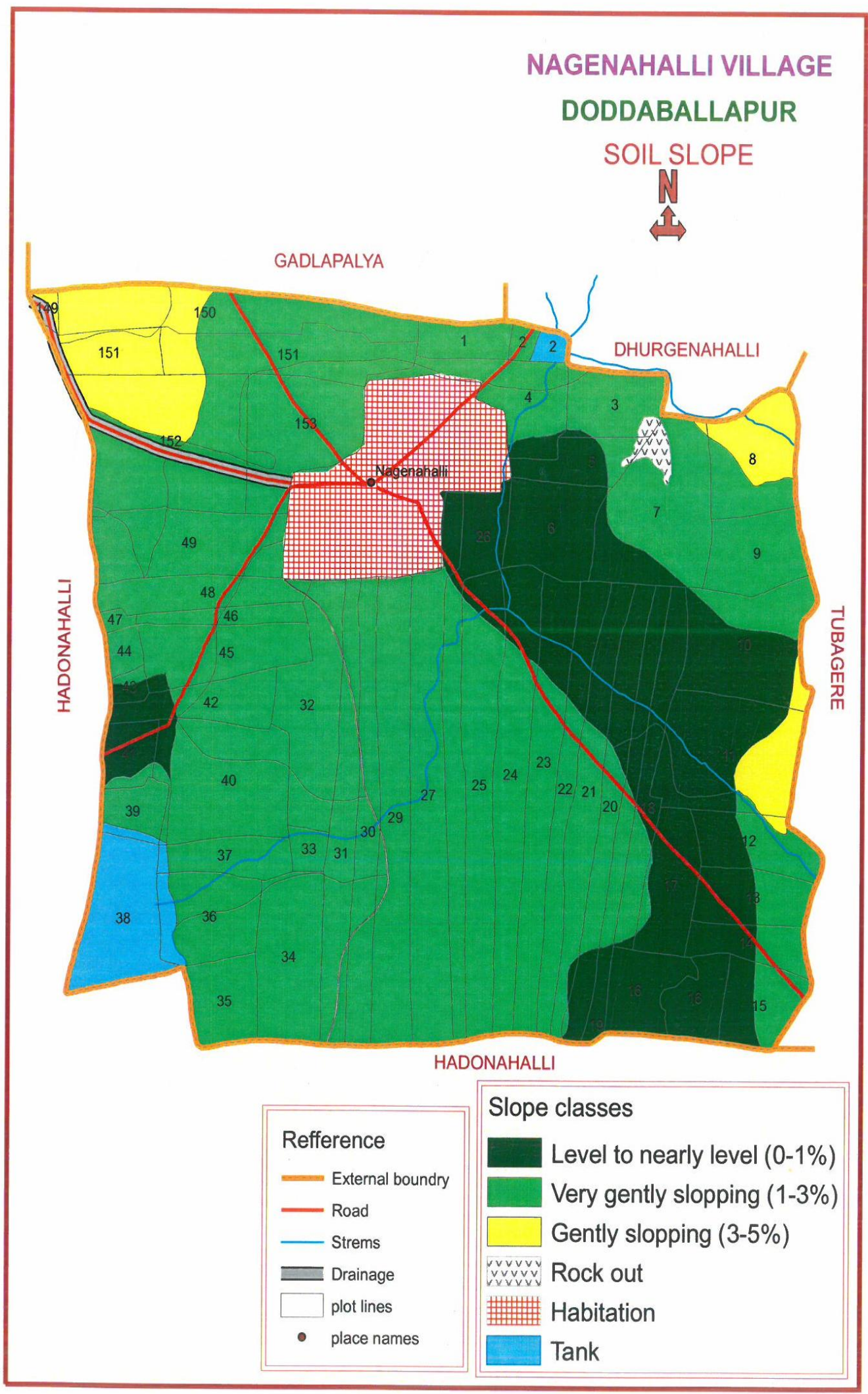


Map.6 Soil erosion map of Nagenahalli village

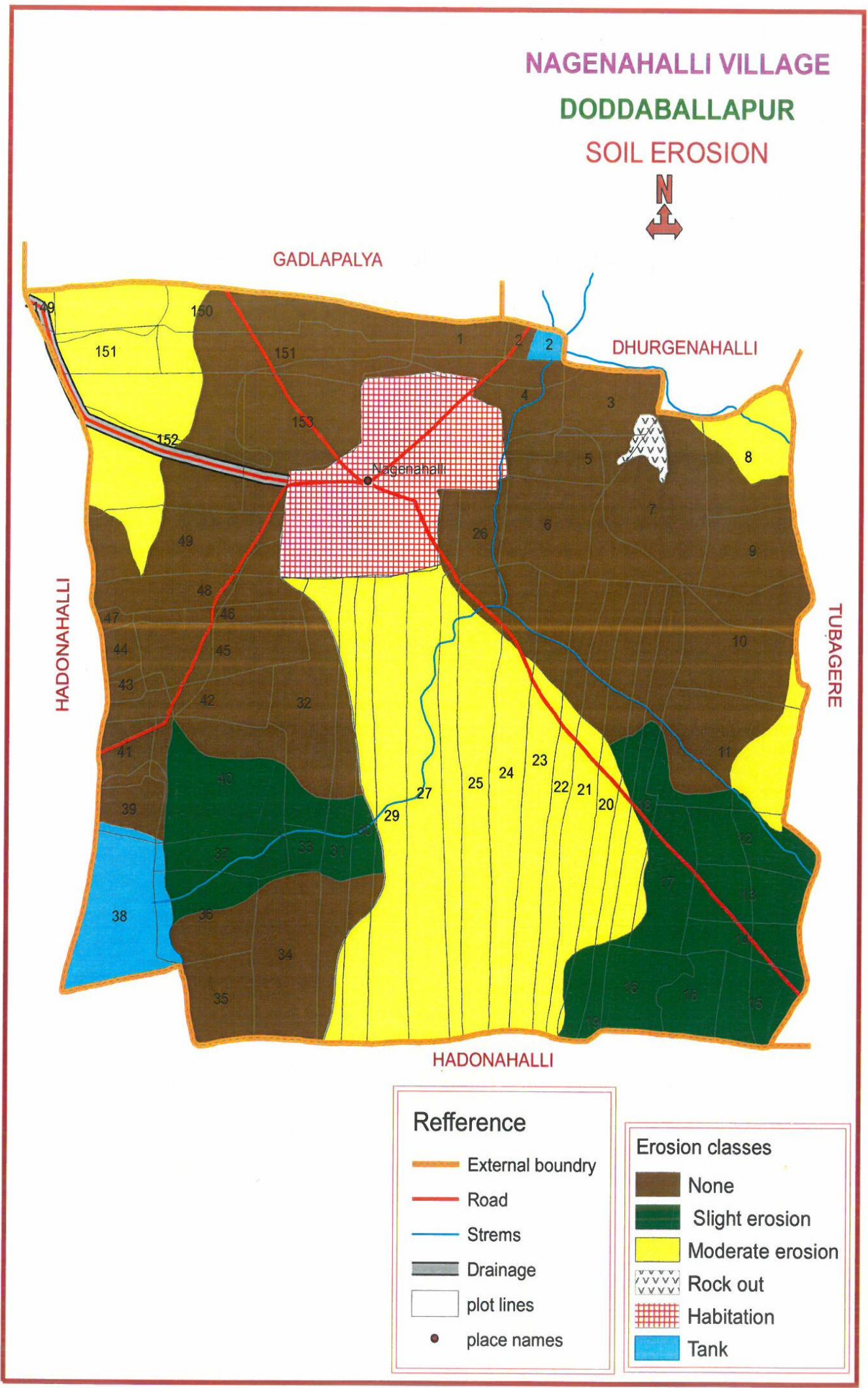


Map.7 Surface soil texture map of Nagenahalli village

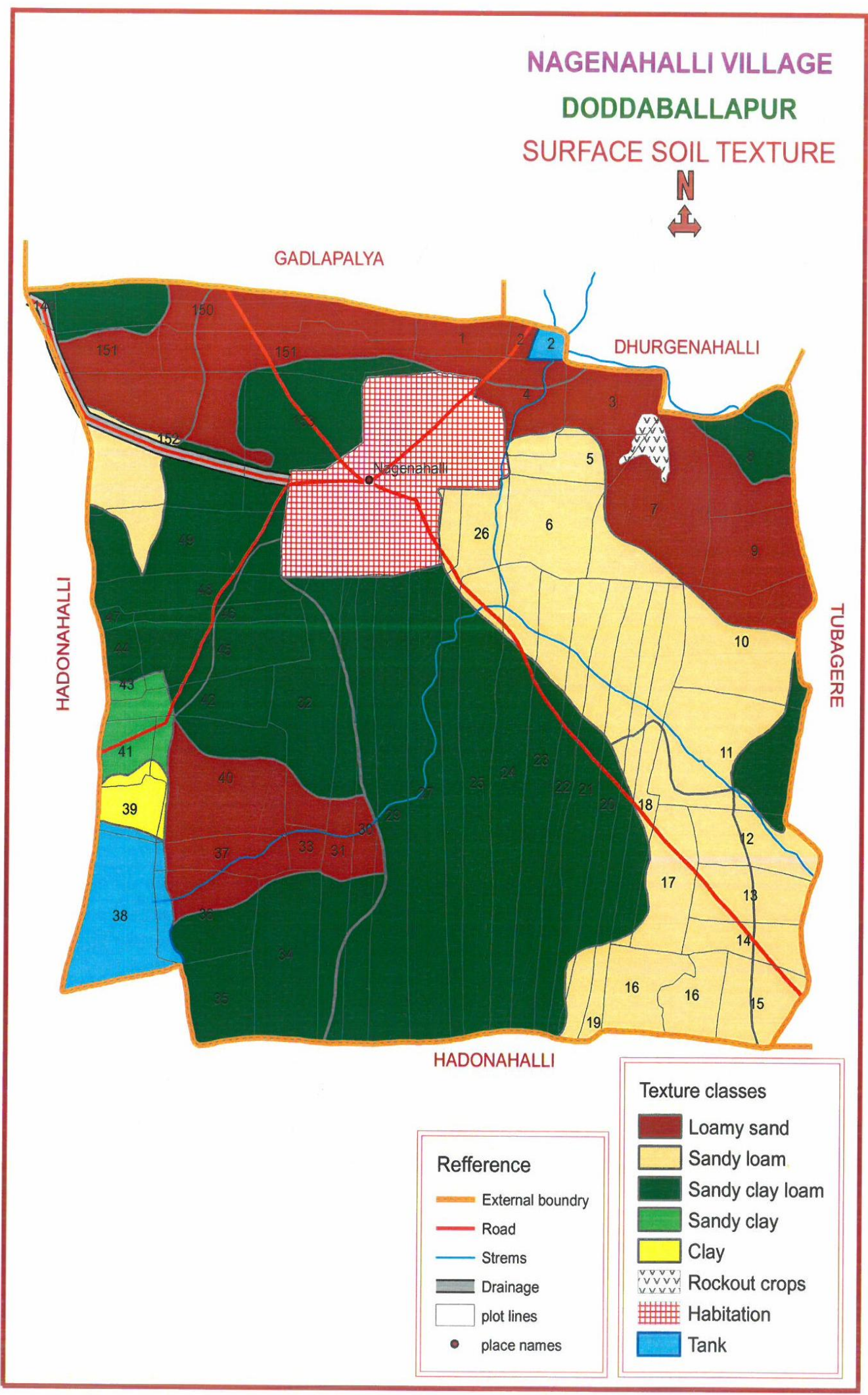


Map.8 Surface rockyness map of Nagenahalli village

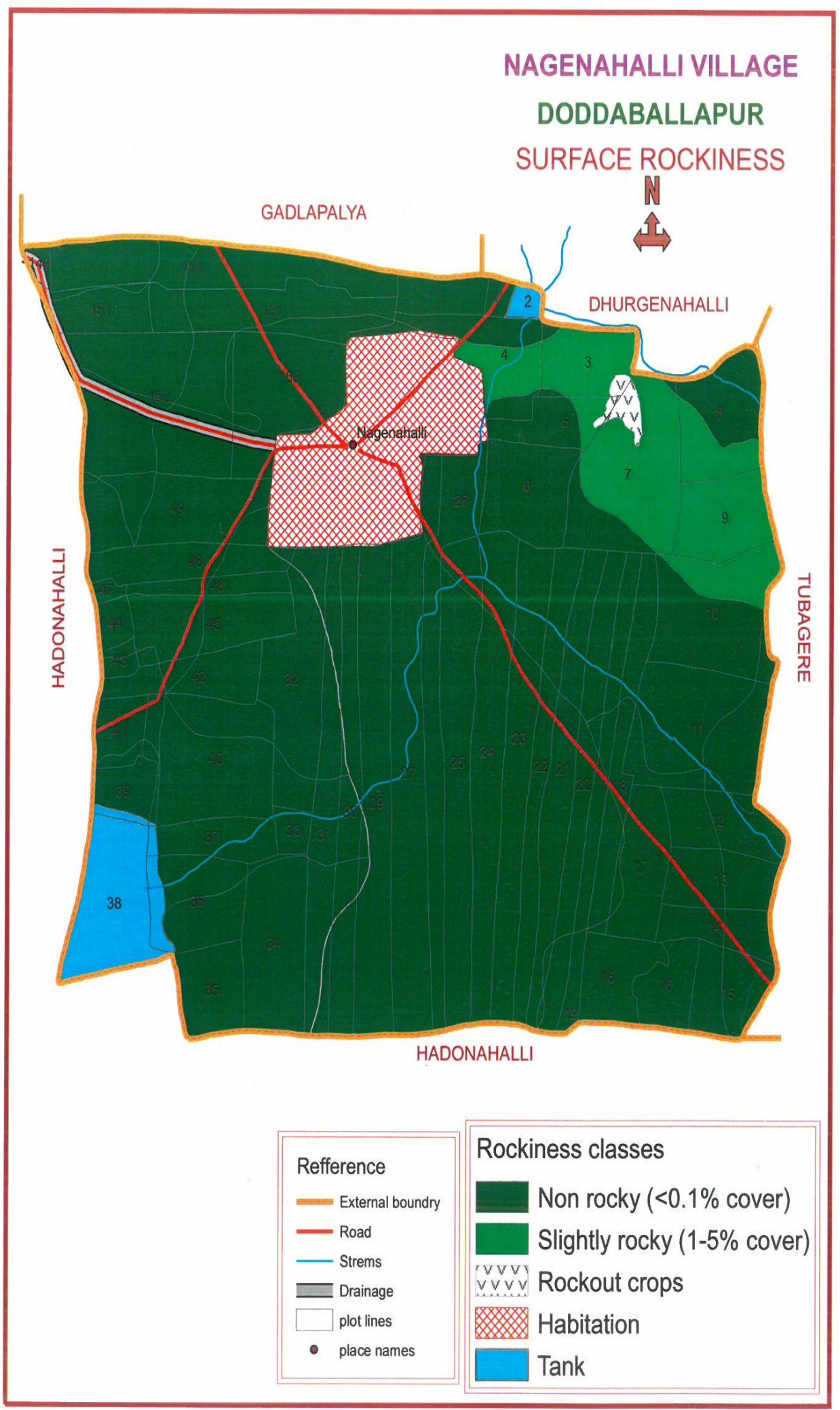




\section{Slope}

Three slope classes were recorded in the village and mapped. Study revealed that 86.6 per cent of the land of the Nagenahalli had very gentle slope, 3.5 per cent with gentle slope and only 0.79 per cent had level to nearly level land.

\section{Soil erosion}

Natural erosion was noticed in the study area which depending on factors like rainfall, slope, soil erodability etc. The water is the main agent responsible for soil erosion in the study area. Sheet erosion is the dominant type of soil erosion observed in very gently to gently sloping uplands. Out of the total area 49 per cent of the land do not experienced erosion risk while 14 per cent experience slight erosion risk and only 27.9 per cent under moderate erosion risk.

\section{Surface soil texture}

The soils of the study are grouped into various textural classes like loamy sand, sandy loam, sandy clay loam, sandy clay and clay. It is one of the important parameter used to identify phases of soil series established.

Sandy clay loam and sandy loam were the dominant texture groups observed in surveyed area. The distribution is sandy clay loam (44 $\%$ ) followed by sandy loam (24.0\%), loamy sand $(20.9 \%)$ and sandy clay $(1.2 \%)$ and clay $(0.8 \%)$ which occurs in a limited extent.

\section{Surface stoniness}

The soils of the whole study area comes under non-gravelly class (0-15\%) which are better for crop production as the gravelliness makes obstruction to free root development of crops and germination of seeds of small seeded crops.

\section{Rockiness}

Rockiness refers to coverage of the soil with exposed rocks, which hinders plant growth directly by impeding root development and through interference of mechanical manipulation and tillage of soil. Out of total study area only 1.1 per cent of the cultivated area experienced slight rockiness.

The various categories identified and their extent of occurrence is given in the table 2 and their distribution is shown in the maps (3, 4, 5, 6, 7 and 8).

In conclusion, the basic data collected from detailed soil survey of Nagenahalli watershed, gave the comprehensive information on the soil resources of the village.

This can be used to assess the problems and potential of the area for agriculture development.

The study revealed that satellite remote sensing technique has been found to be most essential tool for natural resource appraisal of the study area.

The visual interpretation of the satellite imagery supplemented with sufficient ground truth is found to be most efficient and effective way of delineating, demarcating, characterizing and classification of the landscape units.

Based on the interaction among the basic resources of land, water and vegetation which form the major components of primary production system, useful inferences can be drawn about the predicted behavior of these units in meeting the various planning goals. Natural resource development plan, i.e., Action Plan thus can be prepared and crop suitability can be suggested for alternate land use practices for the study area. 


\section{References}

All India Soil and Land Use Survey Organization (AISLUS), (1970). Soil Survey Manual, IARI, New Delhi, 123 Pp.

Anonymous, 1994, Integrated mission for sustainable development Satellite Remote Sensing, Bulletin, DOS, Bangalore

Gowande, S.P., 1990, overview of remote sensing application in soil and land resource management in India. Proc. Natn. Symp. On Dec-6-8, New-Delhi: pp1-10.

Indian Meteorological Department (IMD), (2001) Climatological Tables, 19511980, IMD, Pune, Controller of
Publications, New Delhi, 782 p.

Sathish, A., 2002, Remote sensing and GIS in generation of soil resource information system for agriculture development in Pavagada taluk, Tumkur district. Ph.D. (Agri.) thesis submitted to UAS, Bangalore.

Soil Survey Staff, 1996, Soil survey manual, USDA SCS, Washington DC, US. Some typical soil profiles. J. Indian Soc. Soil Sci., 37:567-570.

Thornthwaite, C.W. and Mather, J.R., 1955. The water balance publication in Climatology (8) 1 Drexel Institute of Technology, Laboratory of Climatology, Centerten, New Jersey, US, $10 \mathrm{Pp}$.

\section{How to cite this article:}

Nalina, C.N., K.S. Anil Kumar, K.G. Shilpa Shree, B. Narendra Babu, K. Sudhir and Natarajan, A. 2017. Inventory and Mapping of Land Resources for Land Use Planning Through Detail Soil Survey Coupled With Remote Sensing and GIS Techniques: A Case Study in Nagenahalli Watershed, Doddaballapur Taluk, Bangalore Rural District. Int.J.Curr.Microbiol.App.Sci. 6(8): 314-331. doi: https://doi.org/10.20546/ijcmas.2017.608.042 